INTERNATIONAL JOURNAL OF RESEARCHES IN BIOSCIENCES, AGRICULTURE AND TECHNOLOGY

(C) VISHWASHANTI MULTIPURPOSE SOCIETY (Global Peace Multipurpose Society) R. No. MH-659/13(N) www.vmsindia.org

\title{
EVALUATION OF ANTIANXIETY AND ANTIDEPRESSANT ACTIVITY OF CESTRUM NOCTURNUM LEAVES
}

\author{
P. Katolkar ${ }^{1}$, S. Bhuskute ${ }^{2}$ and N. Duragkar ${ }^{3}$ \\ ${ }^{1}$ Manoharbhai Patel Institute of Pharmacy (B. Pharm.), Kudwa, Gondia 441614 MS, India \\ ${ }^{2}$ Bhawbhuti Mahavidyalaya, Amgaon, Gondia MS, India \\ ${ }^{3}$ Sharad Pawar College of Pharmacy, Wanadongri, Hingna Road, Nagpur 441110 MS, India \\ p_k_7995@yahoo.co.in
}

\begin{abstract}
:
The present study was designed to evaluate the antianxiety and antidepressant activity of the ethanolic and aqueous extracts of Cestrum nocturnum leaves in rodents. Antianxiety activity was tested by exposing rats to unfamiliar aversion in different methods like elevated plus maze model and actophotometer. The results infer that reduced aversion fear elicits antianxiety activity. The antidepressant activity was tested by using despair swim test and tail suspension test. The results infer that reduced immobility time elicits antidepressant activity. It was concluded that ethanolic and aqueous extracts of Cestrum nocturnum leaves having antianxiety and antidepressant activity. Ethanolic extract of Cestrum nocturnum leaves showing more significant activity over the aqueous extract.

Keywords: Cestrum nocturnum, Antianxiety activity, Antidepressant activity, Elevated plus maze, Actophotometer, Despair swim test.
\end{abstract}

\section{Introduction:}

According to the World Health report [1], approximately 450 million people suffer from mental or behavioral disorders, yet only a small minority of them receives even the most basic treatment. This amounts to $12.3 \%$ of the global burden of disease and will rise to $15 \%$ by 2020 [2]. In the search for new therapeutic products for the treatment of neurological disorders, medicinal plant research, worldwide has progressed constantly demonstrating the pharmacological effectiveness of different plant species in a variety of animal models [3]. Anxiety and depression are extremely dramatic and debilitating multifacetic disorders and it is now becoming clear that without knowledge of clinical and biological aspects of anxiety and depression, it is impossible to offer effective treatment strategies for the patients. Over the past decades, there has been intensive study of a variety of neurobiological aspects of depression and anxiety. Currently the most widely prescribed medications for anxiety disorders are benzodiazepines. But the clinical applications of benzodiazepines as antianxiety agents are limited by their unwanted side effects. Therefore the development of new pharmacological agents from plant sources are well justified.

The genus Cestrum (Solanaceae) with more than 300 species is globally distributed in tropical and subtropical regions throughout the world including India, southern China, Australia, USA and Bangladesh [4] . Several applications of Cestrum have been documented and the toxicity of the species to humans and livestock has been reported $[5,6]$. The leaves of Cestrum have shown significant analgesic and bactericidal activity. Also, inhibitory effect on the central nerve system and cardiac arrhythmic effect of Cestrum is documented and also used for the treatment of burns and swellings [7]. The oil of these species is known to be mosquito repellent and hence $\mathrm{C}$. nocturnum and $\mathrm{C}$. diurnum are used to prevent malaria in African Nations [8]. The study with plant extracts of Cestrum diurnum showed promising activity to combat against larvae of Culex quinquefasciatus (Diptera: Culicidae) and Anopheles stephensi [9]. In this study C. aurantiacum, C. nocturnum and C. diurnum were investigated for phytochemicals and determination of their antioxidant and antimicrobial potential.

\section{Materials and Methods:}

Plant material

Collection and authentication of plant materials

The leaves of Cestrum nocturnum belonging to the family Solanaceae were collected in the month of april 2014 from the local areas of Gondia district, Maharashtra, India. The plant material was identified and authenticated by Department of Botany, Rashtrasant Tukadoji Maharaj Nagpur University, Nagpur was preserved Department of Botany, Rashtrasant Tukadoji Maharaj Nagpur University, Nagpur, Maharashtra, India.

\section{Processing of sample}

Leaves were dried in shade for 25 days and then powdered to get a coarse powder. This powder was stored in an air tight container and used for successive extraction.

Preparation of extracts

Preparation of ethanolic extract of Cestrum nocturnum leaves 
The leaves of Cestrum nocturnum were shade dried and reduced to coarse powder. The standardized coarse powder was evenly packed in the soxhlet apparatus and subjected to defatting with petroleum ether and ethanol extraction. The extract was filtered and filtrate was concentrated by vaccum distillation. Percentage yield of ethanolic extract was found to be $13.8 \%$.

\section{Preparation of aqueous extract of Cestrum nocturnum leaves}

The leaves of Cestrum nocturnum were powdered and extracted by maceration process by using $300 \mathrm{ml}$ of distilled water. In maceration procedure, total amount of $50 \mathrm{~g}$ of powdered leaves were macerated for 3 days it was occasionally stirred at regular intervals of time. It was filtered and concentrated. Then it was dried by rotary evaporator. The percentage yield of aqueous extract was found to be $11.3 \%$.

\section{Phytochemical analysis}

Both the ethanolic and aqueous extracts of Cestrum nocturnum were subjected to preliminary phytochemical screening [10].

\section{Experimental animals}

Wistar rats (150-200 g) and swiss albino mice (18-22g) of either sex were procured from Laboratory Animal Centre, Department of Pharmaceutical Sciences, Rashtrasant Tukadoji Maharaj Nagpur University, Nagpur and acclimatized at the animal house of Sharad Pawar College of Pharmacy, Wanadongri, Hingna Road, Nagpur. All the animals were maintained under standard conditions, that is room temperature $26 \pm 1^{\circ} \mathrm{C}$, relative humidity 45 - 55\% and12:12 h light - dark cycle.

\section{Acute toxicity studies}

Swiss albino mice of either sex (18-22 g weight) were used for acute oral toxicity study. The study was carried out as per the guidelines set by OECD and animals were observed for mortality and behavioural changes [11].

\section{Ethical approval}

The experimental protocols were approved by the Institutional Animal Ethics Committee (IAEC) of Sharad Pawar College of Pharmacy, Wanadongri, Hingna Road, Nagpur. and all the experiments were conducted according to the guidelines of Committee for the Purpose of Control and Supervision on Experiments on Animals (CPCSEA).

\section{Drugs and chemicals}

Fluoxetine (Crescent Therapeutics limited, Himachal Pradesh), Diazepam (Ranbaxy Laboratory limited.), Ethanol (Loba Chemicals Mumbai.).

Antianxiety and antidepressant activity
The ethanolic and aqueous extracts of Cestrum nocturnum leaves were tested for antianxiety activity using elevated plus maze and actophotometer and antidepressant activity using despair swim test and tail suspension test.

\section{Treatment}

Animals were divided into four (I-IV) groups, each group containing six animals

Group I - Control group received distilled water (1ml, p.o).

Group II - Standard group received Diazepam (5mg/kg i.p).

Standard group received Fluoxetine $(10 \mathrm{mg} / \mathrm{kg}$ i.p).

Group III - Test group received ethanolic extract of Cestrum nocturnum (500mg/kg p.o).

Group IV - Test group received aqueous extract of Cestrum nocturnum (500mg/kg p.o).

\section{ANTIANXIETY ACTIVITY}

\section{Elevated plus maze (EPM) model}

The apparatus comprises of two open arms $(35 \times 5 \mathrm{~cm})$ and two closed arms $(30 \times 5 \times 15 \mathrm{~cm})$ that extend from a common central platform $(5 \times 5 \mathrm{~cm})$. The floor and walls of the closed arms are made of wood and painted black. The entire maze is elevated to a height of $50 \mathrm{~cm}$ above the ground level. Rats weighing $(150-200$ gms $)$ were housed in a pair of 10 days prior to the test in the apparatus. During this time the rats were handled by the investigator on alternate days to reduce stress. $30 \mathrm{~min}$ and $60 \mathrm{~min}$ after oral administration of the drug treatment, each rat was placed in the center of the maze facing one of the enclosed arms. During five minutes session, number of entries into open arm and time spent in the open arm were noted [12,13]. The procedure was conducted preferably in a sound attenuated environment.

\section{Locomotor activity}

The locomotor activity can be easily studied with the help of actophotometer, the rats were grouped and treated with drugs. Each animal was placed individually in actophotometer and the basal activity score of all the animals were recorded for $10 \mathrm{mins}$ after 30 and $60 \mathrm{~min}$ of drug treatment [14].

\section{ANTIDEPRESSANT ACTIVITY}

\section{Despair Swim Test Apparatus}

For the determination of antidepressant activity, forced swim test (FST) protocol was employed. During the test, animals were individually placed in a glass cylinder $(20 \mathrm{~cm}$ in height, 14 $\mathrm{cm}$ in diameter) filled with water up to a height of $10 \mathrm{~cm}$, at $25 \pm 2{ }^{\circ} \mathrm{C}$. All animals were forced to swim for $5 \mathrm{~min}$ and the duration of immobility was observed and measured during the $5 \mathrm{~min}$ 
interval of the test. Immobility period was regarded as the time spent by the rats to float in water with no struggle and making only those movements necessary to keep its head above the water. In order to check the fitness level of each test animal, a pre-test was carried out $24 \mathrm{~h}$ before the FST by subjecting each test animal to a session of 15 min swimming.

\section{Tail suspension test}

Tail suspension test was performed based on the method prescribed [15]. The mice were suspended $58 \mathrm{~cm}$ above the floor by means of an adhesive tape, placed approximately $1 \mathrm{~cm}$ from the tip of the tail. The total duration of immobility was quantified during a test period of $5 \mathrm{~min}$. Mice were considered immobile when they were completely remain motionless.

\section{Results and Discussion:}

\section{Acute toxicity}

The acute toxicity study revealed the non toxic nature of all the extracts even at a higher dose of $4 \mathrm{~g} / \mathrm{kg}$ body weight of mice for oral route of administration. For the present study the dose is being selected as $500 \mathrm{mg} / \mathrm{kg}$ p.o.

\section{Phytochemical analysis}

After subjecting to screening, both the ethanolic and aqueous extracts of leaves of Cestrum nocturnum revealed the presence of alkaloids, flavonoids, glycosides, tannins and saponins.

\section{Assessment of antianxiety activity Elevated plus-maze model}

In elevated plus-maze test (EPM), the ethanolic and aqueous extracts of Cestrum nocturnum leaves at a dose of $500 \mathrm{mg} / \mathrm{kg}$ p.o. significantly increased the number of entries and time spent into the open arm. The magnitude of the antianxiety effects $500 \mathrm{mg} / \mathrm{kg}$ p.o. of ethanolic and aqueous extracts of Cestrum nocturnum was comparable to that of diazepam $5 \mathrm{mg} / \mathrm{kg}$ i.p. (Figure 1 and 2).

\section{Actophotometer}

The average of basal activity scores in the control group after 30 and $60 \mathrm{~min}$ of administration of ethanolic and aqueous extracts of Cestrum nocturnum leaves 500 $\mathrm{mg} / \mathrm{kg}$ p.o. significantly reduced the locomotor activity. It may be due to the CNS depressant property of the drug. (Table 1)

\section{Assessment of antidepressant activity}

\section{Despair swim test apparatus}

Table 1: Effect of Ethanolic and Aqueous Extracts of Cestrum nocturnum Leaves on Locomotor Activity (Actophotometer) In Rats At Different Time Intervals.

\begin{tabular}{|l|l|l|l|l|l|}
\hline \multirow{2}{*}{ Group } & Treatment & Photo cell count & \multicolumn{2}{|c|}{ \% change in activity } \\
\cline { 3 - 6 } & & $30 \mathrm{~min}$ & $60 \mathrm{~min}$ & $30 \mathrm{~min}$ & $60 \mathrm{~min}$ \\
\hline I & Control (Vehicle) & $306 \pm 5.032$ & $307.1 \pm 4.132$ & $\mathrm{NA}$ & NA \\
\hline II & Diazepam & $119 \pm 1.581^{*}$ & $84.67 \pm 2.789^{*}$ & 61.1 & 72.45 \\
\hline III & Ethanolic extract & $145.7 \pm 4.910^{*}$ & $97.33 \pm 1.856^{*}$ & 52.4 & 68.35 \\
\hline IV & Aqueous Extract & $167.3 \pm 2.404^{*}$ & $118.3 \pm 1.453^{*}$ & 45.32 & 61.53 \\
\hline
\end{tabular}

In despair swim test apparatus, the ethanolic and aqueous extracts of leaves of Cestrum nocturnum at a dose of $500 \mathrm{mg} / \mathrm{kg}$ p.o. significantly decreased the immobility time. The magnitude of the antidepressant effects of 500 $\mathrm{mg} / \mathrm{kg}$ p.o. of ethanolic and aqueous extracts of leaves of Cestrum nocturnum was comparable to that of fluoxetine $10 \mathrm{mg} / \mathrm{kg}$ i.p. (Table 2).

\section{Tail suspension test}

In tail suspension test, the ethanolic and aqueous extracts of leaves of Cestrum nocturnum at a dose of $500 \mathrm{mg} / \mathrm{kg}$ p.o. significantly decreased the immobility time. The magnitude of the antidepressant effects of $500 \mathrm{mg} / \mathrm{kg}$ p.o. of ethanolic and aqueous leaves of Cestrum nocturnum was comparable to that of fluoxetine $10 \mathrm{mg} / \mathrm{kg}$ i.p. (Table 3).

The fear due to height induces anxiety in the animals when placed on the EPM. The ultimate manifestation of anxiety and fear in the animals is exhibited by decrease in the motor activity and preference to remain at safer places. Antianxiety agents are expected to increase the motor activity, which is measured by the time spent by the animal in the open arms. The spontaneous decrease in basal activity score implicates the reduced anxiety recorded using actophotometer. The widespread use of FST is mainly due to its ability to detect a broad spectrum of antidepressant agents. The test is based on the observation that rodents following initial escape-oriented movements develop an immobile posture when placed inside an inescapable cylinder filled with water. The immobility is thought to reflect either a failure of persistence in escape-directed behavior (i.e., despair behavior) or the development of a passive behavior, meaning the loss of the animal's ability to cope with stressful stimuli. Markedly showed a significant decrease in the time spent immobile by rodents. By performing tail suspension test, the reduced immobility time directed the antidepressant effect. The antianxiety and antidepressant effects may be due to the flavonoid [16] content present in both the extracts of Cestrum nocturnum. However, further studies are required to identify the phytoconstituents responsible for the observed antianxiety and anti-depressant effect. 
NA-Not Applicable, ${ }^{*} \mathrm{p}<0.001$ when compared to control

Table 2: Effect of Ethanolic and Aqueous Extracts of Cestrum nocturnum Leaves Despair Swim Test In Rats At Different Time Intervals.

\begin{tabular}{|l|l|l|l|l|l|}
\hline \multirow{2}{*}{ Group } & Treatment & Photo cell count $(\mathrm{sec} / 5 \mathrm{~min})$ & \multicolumn{2}{l|}{ \% change in activity } \\
\cline { 3 - 6 } & & $30 \mathrm{~min}$ & $60 \mathrm{~min}$ & $30 \mathrm{~min}$ & $60 \mathrm{~min}$ \\
\hline I & Control (Vehicle) & $186.7 \pm 4.410$ & $188 \pm 4.583$ & NA & NA \\
\hline II & Fluoxetine & $88.33 \pm 1.453^{*}$ & $56.33 \pm 1.453^{*}$ & 52.6 & 70.0 \\
\hline III & Ethanolic extract & $98.67 \pm 2.028^{*}$ & $68 \pm 1.856^{*}$ & 47.15 & 63.8 \\
\hline IV & Aqueous Extract & $111.7 \pm 3.338^{*}$ & $83.33 \pm 2.404^{*}$ & 55.69 & 55.69 \\
\hline
\end{tabular}

NA-Not Applicable, ${ }^{*} \mathrm{p}<0.001$ when compared to control

Table 3: Effect of Ethanolic and Aqueous Extracts of Cestrum nocturnum Leaves Tail Suspension Test In Rats At Different Time Intervals.

\begin{tabular}{|l|l|l|l|l|l|}
\hline \multirow{2}{*}{ Group } & Treatment & \multicolumn{2}{|l|}{ Photo cell count $(\mathrm{sec} / 5 \mathrm{~min})$} & \multicolumn{2}{l|}{ \% change in activity } \\
\cline { 3 - 6 } & & $30 \mathrm{~min}$ & $60 \mathrm{~min}$ & $30 \mathrm{~min}$ & $60 \mathrm{~min}$ \\
\hline I & Control (Vehicle) & $105.7 \pm 3.480$ & $107.3 \pm 3.528$ & NA & NA \\
\hline II & Fluoxetine & $38.3 \pm 1.453^{*}$ & $36.6 \pm 1.202^{*}$ & 63.73 & 68.89 \\
\hline III & Ethanolic extract & $35.33 \pm 1.764^{*}$ & $27.33 \pm 2.906^{*}$ & 66.57 & 74.55 \\
\hline IV & Aqueous Extract & $58.67 \pm 1.764^{*}$ & $44.33 \pm 2.33^{*}$ & 44.50 & 58.99 \\
\hline
\end{tabular}

NA-Not Applicable, ${ }^{*} \mathrm{p}<0.001$ when compared to control

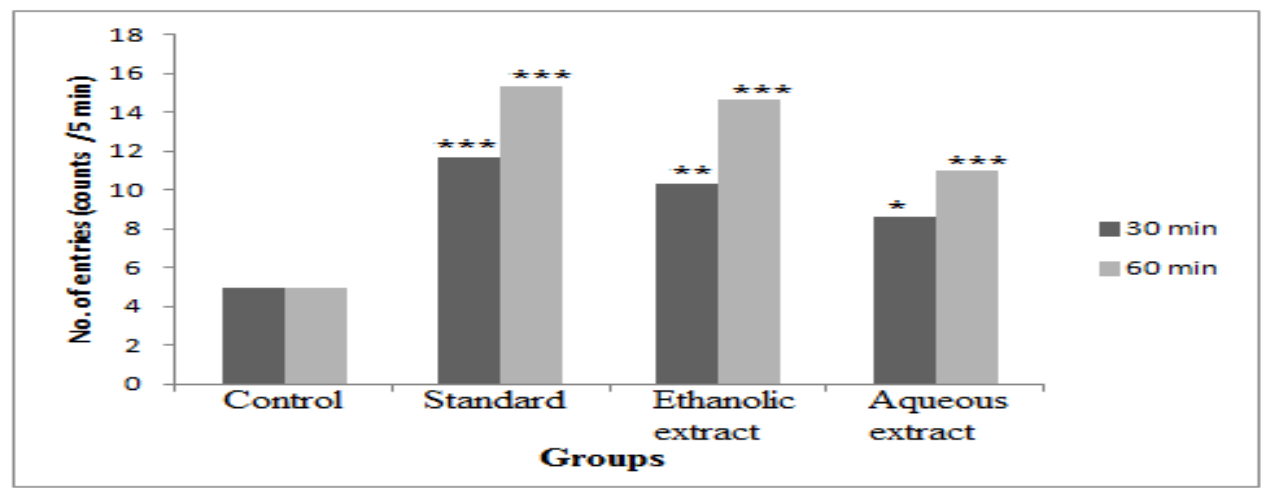

${ }^{* * *} \mathbf{p}<0.001,{ }^{* *} \mathbf{p}<0.01{ }^{*} \mathbf{p}<0.1$ when compared to Control

Fig. 1: Effect of ethanolic and aqueous extracts of Cestrum nocturnum leaves on number of entries (open arm) in elevated plus maze.

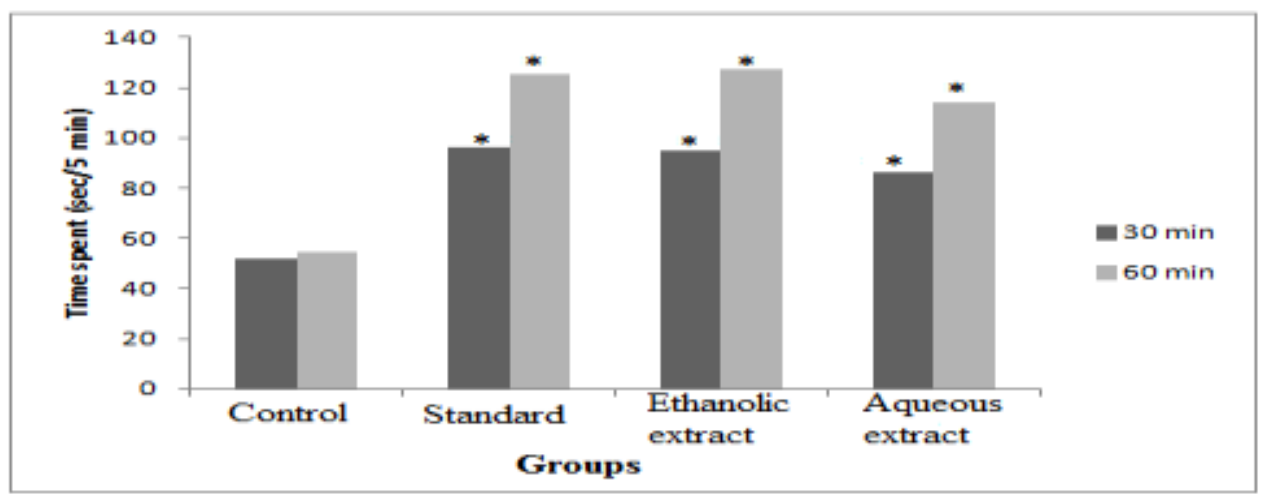

${ }^{*} \mathbf{p}<0.001$ when compared to Control

Fig . 2 : Effect of ethanolic and aqueous extracts of Cestrum nocturnum leaves on time spent (open arm) in elevated plus maze

\section{Conclusion:}

From the results it was concluded that both ethanolic and aqueous extracts of leaves of Cestrum nocturnum showed antianxiety and anti-depressant activity. These findings suggest that the ethanolic extract of Cestrum nocturnum leaves posses more significant antianxiety and anti-depressant activity compared to aqueous extract.

\section{Statistical analysis}

The results were expressed as mean \pm S.E.M. The differences were compared using one way analysis of variance (ANOVA) and subsequently followed by Bonferroni's test. 


\section{References:}

1) WHO. The World Health Report. Mental health: New understanding new hope. WHO, Geneva 2001.

2) Reynolds EH. Brain and mind: a challenge for WHO. Lancet 2003; 361: 1924-1925.

3) Zhang ZJ. Therapeutic effects of herbal extracts and constituents in animal models of psychiatric disorders. Life Science 2004; 75: 1659-1699.

4) Sharif M, Rahman A, Kang SC, Chemical composition and inhibitory effect of essential oil and organic extracts of Cestrum nocturnum L. on food-borne pathogens, Int $\mathrm{J}$ Food Sci Tech, 2009;44: 1176-1182.

5) Mello JRB, Calcinosis-calcinogenic plants (Review), Toxicon, 2003;41(1): 1-12.

6) Stone B, The flora of Guam, Micronesica, 1970;6: 516.

7)Huang LG, Zhang XC, Xiao H, Ye HY, Zeng $\mathbf{J}$, Analgesic effect of Cestrum nocturnum L. extract on mice, Chin. J. Clin. Rehab, 2006;10: 172-174.

8) Ntonifor NN, Ngufor CA, Kimbi HK and Oben BO, Traditional use of mosquito repellent to protect human against mosquito and other insect bites in rural community of Cameroon, East Afr Med J, 2006;83: 553-558.

9) Ghosh A, Chandra G, Biocontrol efficacy of Cestrum diurnum L. (Solanaceae: Solanales) against the larval forms of Anopheles stephensi, Nat Prod Res, 2006;20: 371-79.
10) Kudav, N.A. and Kulakarni A.B. Chemical investigation of Cestrum nocturnum. Indian J. Chem., 1947; 12: 10421044.

11) Sini1 K.R, Sinha B.N, Karpakavalli M, Sangeetha P.T, Analgesic and antipyretic activity of Cestrum nocturnum Linn. Annals of Biological Research, 2011, 2 (1): 195-200.

12) Rodgers RJ, Johnson NJT. Behaviorally selective effects of neuroactive steroids on plus-maze anxiety in mice. Pharmacol. Biochem. Behav., 1998; 59: 221 232.

13) Pellow S, File SE. Anxiolytic and axiogenic drug effects on exploratory activity in an elevated plus-maze: a novel test of anxiety in the rat. Pharmacol. Biochem. Behav., 1986; 24: 525-529.

14) Alagarswamy V, Thangathiruppathy A, Mandal SC, Rajasekaran S, Vijaykumar S, Revathi. Pharmacological evaluation of 2substituted $(1,3,4)$ thiadiazolo quinazolines. Ind. J. Pharm. Sci., 2006; 68(1): 108-111.

15) Steru, L., Chermat, R., Thierry, B. \& Simon,B. The tail suspension test: A method for screening antidepressants in mice. Psychopharmacology 1985; 85: 367-370.

16) Vikas Gupta, Parveen Bansal., Pawan Kumar., Richa Shri., anxiolytic and antidepressant activities of different extracts from citrus paradisi var. Duncan. Asian Journal of Pharmaceutical and Clinical Research. 98-99. 